\title{
Chrysoperla externa (NEUROPTERA: CHRYSOPIDAE) AND Utetheisa ornatrix (LEPIDOPTERA: ARCTIIDAE) ON ORGANICALLY GROWN Crotalaria juncea (FABACEAE) ${ }^{1}$
}

\author{
Chrysoperla externa (Neuroptera: Chrysopidae) e Utetheisa ornatrix (Lepidoptera: Arctiidae) \\ sobre Crotalaria juncea (Fabaceae) Cultivada Organicamente
}

\begin{abstract}
COSTA, M.A. ${ }^{2}$, TAVARES, W.S. ${ }^{3}$, PEREIRA, A.I.A. ${ }^{4}$, CRUZ, I. ${ }^{5}$, SERRÃO, J.E. ${ }^{6}$, and ZANUNCIO, J.C. ${ }^{7}$
ABSTRACT - Chrysoperla externa (Neuroptera: Chrysopidae) larvae can avoid foraging on plants of Crotalaria juncea (Fabaceae) after the issuance of floral buds, when the prey of Utetheisa ornatrix (Lepidoptera: Arctiidae) incorporate toxic pyrrolizidine alkaloids from this plant. This reduces the predation and favors increasing the number of adults and eggs of this defoliator on crops of this plant. The aim of the present paper was to evaluate some biological and ecological aspects of $C$. externa and $U$. ornatrix on the organic crop of $C$. juncea in the EMBRAPA Maize and Sorghum in Sete Lagoas, Minas Gerais State, Brazil. Chrysoperla externa and $U$. ornatrix were more abundant in the vegetative and flowering stages of $C$. juncea, respectively, with caterpillars of this defoliator feeding on leaves and seeds of this plant. The duration of the stages/instars, survival, lifetime fecundity, and oviposition showed that the branches of $C$. juncea are a suitable food for $U$. ornatrix. The abundance of adults and larvae of $C$. externa was lower in the flowering and pods stages of $C$. juncea, respectively, when the postures of $U$. ornatrix are present, probably due to the toxicity of the eggs of this prey to this predator. During these stages, C. externa may be reared with alternative hosts, and when the crops of C. juncea are scarce, an artificial diet should be used for rearing this defoliator in the laboratory for biological research and the development of biological control tactics.
\end{abstract}

Keywords: biological control, crotalaria month, green lacewing, green manure, Integrated Pest Management.

\begin{abstract}
RESUMO - Larvas de Chrysoperla externa (Neuroptera: Chrysopidae) podem evitar o forrageamento sobre plantas de Crotalaria juncea (Fabaceae) após a emissão de botões florais, quando presas de Utetheisa ornatrix (Lepidoptera: Arctiidae) incorporam alcalóides pirrolizidinicos tóxicos dessa planta. Isso reduz a predação e favorece o aumento do número de adultos e ovos desse desfolhador sobre cultivos dessa planta. O objetivo deste trabalho foi avaliar alguns aspectos biológicos e ecológicos de C. externa e U. ornatrix sobre cultivo orgânico de C. juncea na EMBRAPA Milho e Sorgo, em Sete Lagoas, Minas Gerais, Brasil. Chrysoperla externa e U. ornatrix foram mais abundantes nos estádios vegetativo e de florescimento de $\boldsymbol{C}$. juncea, respectivamente, com lagartas desse desfolhador se alimentando sobre folhas e sementes dessa planta. A duração dos estágios/ estádios, sobrevivência, fecundidade de vida e oviposição mostraram que ramos de C. juncea é um alimento adequado para $\boldsymbol{U}$. ornatrix. A abundância de adultos e larvas de C. externa foi menor nas fases de floração e vagens de C. juncea, respectivamente, quando posturas de $\boldsymbol{U}$. ornatrix estiveram presentes, provavelmente devido à toxicidade de ovos dessa presa a esse predador. Durante esses estádios, C. externa pode ser criado com hospedeiros alternativos, e, quando cultivos de C. juncea são escassos, uma dieta artificial deve ser usada para criação desse desfolhador em laboratório, para pesquisas biológicas e desenvolvimento de táticas de controle biológico.
\end{abstract}

Palavras-chave: controle biológico, lagarta-das-crotalárias, crisopídeo, adubação verde, Manejo Integrado de Pragas.

Recebido para publicação em 3.12.2011 e aprovado em 6.7.2012.

2 Dep. de Entomologia, Universidade Federal de Lavras - DEN/UFLA, 37200-000 Lavras, Minas Gerais State, Brazil, <marianaabreuc@yahoo.com.br>; ${ }^{3}$ Programa de Pós-Graduação em Fitotecnia, Universidade Federal de Viçosa - DFT/UFV, 36570-000 Viçosa, Minas Gerais State, Brazil, <wagner.tavares@ufv.br>; ${ }^{4}$ Instituto Federal Goiano, Campus Irutaí - IFGOIANO, $75790-000$ Urutaí, Goiás State, Brazil, <aiapereira@yahoo.com.br>; ${ }^{5}$ Embrapa Milho e Sorgo, Rodovia MG 424, Km 65, Caixa Postal 151, 35701-970 Sete Lagoas, Minas Gerais State, Brazil, <ivancruz@cnpms.embrapa.br>; ${ }^{6}$ Dep. de Biologia Geral, DBG/UFV, $<$ jeserrao@ufv.br>; ${ }^{7}$ Dep. de Biologia Animal, DBA/UFV, <zanuncio@ufv.br>.

Planta Daninha, Viçosa-MG, v. 30, n. 3, p. 459-468, 2012 


\section{INTRODUCTION}

Crotalaria juncea (Fabaceae) plants fix atmospheric nitrogen and are used as green manure, thereby suppressing weeds (Miyazawa et al., 2010; Queiroz et al., 2010). In addition, this plant presents antagonism to nematodes (Hooks et al., 2010) and to other harmful animals (Johnson et al., 1985; Ji et al., 2005), has the ability to grow in infertile soils, although it may not have good development (Monquero et al., 2009; Odhiambo, 2011), good resistance to drought (Meschede et al., 2007; Calonego \& Rosolem, 2010), and its fibers are used in the paper industry due to their softness and resistance (Morris \& Kays, 2005). The area cultivated with $C$. juncea in Brazil is 3,000 ha (Signoretti et al., 2008). However, the expansion of this crop is limited due to a shortage of seed supply (Wander et al., 2007) and few regions with a suitable photoperiod for its development (Martins et al., 2009).

Utetheisa ornatrix, 1758 (Lepidoptera: Arctiidae) is the most important defoliator of Crotalaria spp. (Crotalaria anagyroides, Crotalaria falsajuncea, C. juncea, Crotalaria stipularia, Crotalaria usaramohensis, and Crotalaria vitellina) (Fabaceae) in Brazil (Cogni \& Futuyma, 2009; Dias et al., 2009), but damages other plant species in the northern and eastern Andes in South America (Argentina, Brazil, and Chile) (Diniz et al., 2010). Their caterpillars feed on floral buds, green pods, and seeds in the development of Crotalaria spp. (Ferro et al., 2006; Cogni, 2010).

Utetheisa ornatrix caterpillars incorporate pyrrolizidine alkaloids (PAs) after feeding on plants of Crotalaria spp. and keep these toxic substances in the body (Hartmann et al., 2004; Campo et al., 2005; Guimarães Junior et al., 2006). Adult females of this defoliator may transfer toxic PAs to their egg shells to favor protection against natural enemies, which are mainly the larvae of Chrysopidae and ants (Eisner et al., 2000). The number of larvae of Chrysopidae seems to be greater in the vegetative stage of $C$. juncea; $U$. ornatrix appears to have a higher number of adults and caterpillars after the issuance of floral buds of C. juncea (personal observation, Wagner de Souza Tavares). Chrysopidae larvae may feed on another prey in the vegetative stage of
C. juncea or migrate to crops of other species after the issuance of floral buds by this Fabaceae to avoid feeding on the toxic eggs of this defoliator (personal observation, Wagner de Souza Tavares).

The hypothesis tested was that Chrysoperla externa Hagen, 1861 (Neuroptera: Chrysopidae) avoid crops of C. juncea after the issuance of floral buds by this plant and, therefore, the number of adults and eggs of $U$. ornatrix could be higher in this stage.

The aim of the present paper was to evaluate some biological and ecological aspects of beneficial C. externa and harmful $U$. ornatrix on the organic crop of $C$. juncea.

\section{MATERIALS AND METHODS}

Crotalaria juncea has been cultivated in an area without pesticides during the last 15 years in the EMBRAPA Maize and Sorghum in Sete Lagoas, Minas Gerais State, Brazil.

The experiment was carried out in the field and laboratory of the EMBRAPA Maize and Sorghum. Crotalaria juncea was sown in December 28, 2006 (19 $28^{\circ} \mathrm{S}, 4^{\circ} 15^{\circ} \mathrm{W}, 750 \mathrm{~m}$ above sea level) and no pesticides were used. Weeds were manually removed. Rainfall was the lowest in August $(6.3 \mathrm{~mm})$; the relative humidity was the lowest in August and September (62\%) and the highest in December (78\%), January and February $(77 \%)$, with an annual amplitude of $16 \%$. The maximum wind speed was the highest in September and October $\left(2.1 \mathrm{~m} \mathrm{~s}^{-1}\right)$ and the lowest in April, May and June $\left(1.5 \mathrm{~m} \mathrm{~s}^{-1}\right)$. This region can be characterized as semi-moist.

Two hectares with Red Yellow Latosol Distroferric-type soil were implanted with C. juncea in a space of $70 \mathrm{~cm}$ between rows and $10 \mathrm{~cm}$ between plants and divided in six plots of $200 \mathrm{~m}^{2}$ (10 m wide x $20 \mathrm{~m}$ long) each. The predominant crop in this region is C. juncea, followed by Zea mays or Sorghum bicolor (Poaceae). Soil chemical analysis (upper 20-cm layer) showed $\mathrm{pH}\left(\mathrm{H}_{2} \mathrm{O}\right)=5.8$; $\mathrm{H}+\mathrm{Al}^{+3}=5.6 ; \mathrm{Al}^{+3}=0.0 ; \mathrm{Ca}^{+2}=2.71 ; \mathrm{Mg}^{+2}=0.51 ;$ $\mathrm{SB}=3.43$ and $\mathrm{CTC}=9.03 \mathrm{cmol}_{\mathrm{c}} \mathrm{dm}^{-3} ; \mathrm{K}=84$ and $\mathrm{P}=17 \mathrm{mg} \mathrm{dm}^{-3} ; \mathrm{M} . \mathrm{O} .=3.94 \mathrm{dag} \mathrm{kg}^{-1}$ and $\mathrm{V}=38$ and $\mathrm{Sat} \mathrm{Al}=\mathrm{O}$. In the laboratory, the experiment was conducted in an acclimatized room at 
$25 \pm 1{ }^{\circ} \mathrm{C}$ temperature, $70 \pm 10 \%$ relative humidity, and $12 \mathrm{~h}$ photoperiod in the Laboratory of Insect Rearing (LACRI).

Larvae and adults of Chrysopidae and caterpillars of Lepidoptera were collected from the $12^{\text {th }}$ day of plant emergence (vegetative stage) to the pods stage of $C$. juncea. These samples were collected every three days, in the vegetative, flowering $(50 \%+$ a plant with flower) and pods (50\% + a plant with pods) stages from 08:00 to $12: 00$ using an insect net. This insect net was passed in a zigzag motion in two lines of culture (Ábrahám et al., 2003). The insects collected were transferred to plastic bags (5 1) and taken to the laboratory.

Larvae of Chrysopidae were maintained until the adult stage with an artificial diet (45 g honey, $45 \mathrm{~g}$ yeast, and $10 \mathrm{~mL}$ distilled water) in Polyvinyl chloride (PVC) tubes (Tavares et al., 2011a). Specimens of these adults were sent to Dr. Sergio de Freitas (in memoriam) of the Faculdade de Ciências Agrárias e Veterinárias (FCAV), Universidade Estadual Paulista "Júlio de Mesquita Filho" (UNESP) in Jaboticabal, São Paulo State, Brazil, and identified as C. externa. Caterpillars of Lepidoptera were maintained until the adult stage with an artificial diet (130 g white beans, $30 \mathrm{~g}$ carrot, $20 \mathrm{~g}$ yeast extract, $40 \mathrm{~mL}$ vitamin solution, $2 \mathrm{~mL}$ Vitagold ${ }^{\circledR}, 1.6 \mathrm{~g}$ ascorbic acid, $0.6 \mathrm{~g}$ sorbic acid, $1.1 \mathrm{~g}$ nipagin, $0.4 \mathrm{~mL}$ propionic acid, $0.3 \mathrm{mg}$ Tetrex $\mathbb{R}, 1 \mathrm{~mL} 40 \%$ formaldehyde in distilled water, $7 \mathrm{~g}$ agar, and $500 \mathrm{~mL}$ distilled water) in PVC tubes. The vitamin solution consisted of $1 \mathrm{mg}$ niacinamide, $1 \mathrm{mg}$ calcium pantothenate, $1 \mathrm{mg}$ thiamine, $0.25 \mathrm{mg}$ riboflavin, $0.25 \mathrm{mg}$ pyridoxine, $0.25 \mathrm{mg}$ folic acid, $0.02 \mathrm{mg}$ biotin, $0.002 \mathrm{mg}$ vitamin B12, and $20 \mathrm{mg}$ inositol (Signoretti et al., 2008). Pupae of these insects were placed in plastic trays covered with filter paper moistened daily, and their adults maintained with $10 \%$ honey in distilled water. Specimens of these adults were sent to the Departamento de Engenharia Florestal (DEF), Universidade Federal dos Vales do Jequitinhonha e Mucuri (UFVJM) in Diamantina, Minas Gerais State, Brazil, and identified as U. ornatrix by Dr. Sebastião Lourenço de Assis Júnior.
Newly-hatched caterpillars of the second generation were removed from the $U$. ornatrix colony and fed with leaves from the middle portion of branches in the vegetative stage of C. juncea. Leaves were replaced on a daily basis. The stems of these branches were placed in glass tubes with water to reduce leaf wilting. These caterpillars were maintained in PVC tubes, whose inner wall was covered with white A4 paper as a substrate for oviposition. The duration of the stages/ instars, survival, lifetime fecundity, and oviposition; some parameters of ecology and morphology of eggs, larvae, pupae and adults of $U$. ornatrix were evaluated when their caterpillars fed on C. juncea.

The experimental design was a Complete Randomized Block (CRB) with six replications (each repetition, a $200 \mathrm{~m}^{2}$ plot cultivated with $C$. juncea). The insect's abundance (C. externa and $U$. ornatrix) was assessed on the total of individuals collected in the plots. The data were transformed in $\sqrt{ } \mathrm{X}+0.5$ and submitted to variance analysis (ANOVA) with split plots. Each plot was represented by the six cultivated areas $\left(200 \mathrm{~m}^{2}\right.$ each) and sub plots by the phenological stages of $C$. juncea (vegetative, flowering, and pods). The total number of insects by the phenological stage of $C$. juncea was compared by Tukey's test $(P<0.05)$ with the MSTAT-C software, version 2.1 (Supplier: EMBRAPA Maize and Sorghum) (Russel, 1989).

\section{RESULTS}

Utetheisa ornatrix has five instars on the plants of $C$. juncea, but some caterpillars of this species showed six instars; the number of individuals and survival of stages/instars of $U$. ornatrix after feeding with the plants of C. juncea were described (Table 1).

The duration of the stages/instars of $U$. ornatrix after feeding on the plants of C. juncea were placed (Table 2).

The lifetime fecundity of $U$. ornatrix was 459.3 with 10.3 of oviposition for 14 females (Table 3).

Utetheisa ornatrix eggs have circular shape with $0.66 \mathrm{~mm}$ diameter. The newest exhibit creamy yellow color, darkening with the age and become black near the hatching.

Planta Daninha, Viçosa-MG, v. 30, n. 3, p. 459-468, 2012 
Table 1 - Number of individuals and survival (\%) (mean \pm standard error of mean) of stages/instars of Utetheisa ornatrix (Lepidoptera: Arctiidae) after feeding on Crotalaria juncea (Fabaceae) plants in the laboratory

\begin{tabular}{|c|c|c|c|c|c|}
\hline Stages/instars & $\mathrm{Ni}$ & $\mathrm{Su}$ & $\mathrm{R}$ & $\mathrm{Sa}$ & $\mathrm{R}$ \\
\hline Egg & 108 & - & - & - & - \\
\hline $1^{\mathrm{o}}$ instar & 108 & $100.0 \pm 0.00$ & 0.00 & $100.0 \pm 0.00$ & 0.00 \\
\hline $2^{\mathrm{o}}$ instar & 107 & $99.0 \pm 0.01$ & 0.02 & $99.0 \pm 0.01$ & 0.02 \\
\hline $3^{\mathrm{o}}$ instar & 105 & $98.1 \pm 0.96$ & 1.92 & $97.2 \pm 0.97$ & 1.94 \\
\hline $4^{\mathrm{o}}$ instar & 105 & $100.0 \pm 0.00$ & 0.00 & $97.2 \pm 0.97$ & 1.94 \\
\hline $5^{\mathrm{o}}$ instar & 105 & $100.0 \pm 0.00$ & 0.00 & $97.2 \pm 0.97$ & 1.94 \\
\hline Pupa & 48 & $45.7 \pm 0.46$ & 0.92 & $44.4 \pm 0.44$ & 0.88 \\
\hline Adult & 36 & $75.0 \pm 0.75$ & 1.50 & $33.3 \pm 0.33$ & 0.66 \\
\hline
\end{tabular}

$\mathrm{Ni}=$ Number of individuals; $\mathrm{Su}=$ Survival; $\mathrm{Sa}=$ Survival accumulated; $\mathrm{R}=$ Range $(\%)$.

Table 2 - Maximum, minimum, and average (mean \pm standard error of mean) of duration of the stages/instars (days) of Utetheisa ornatrix (Lepidoptera: Arctiidae) after feeding on Crotalaria juncea (Fabaceae) plants in the laboratory

\begin{tabular}{|c|c|c|c|c|c|c|}
\hline \multirow{2}{*}{ Stages/instars } & \multicolumn{6}{|c|}{ Duration (days) } \\
\hline & $\mathrm{Ma}$ & $\mathrm{R}$ & Mi & $\mathrm{R}$ & Av & $\mathrm{R}$ \\
\hline Egg & $8 \pm 0.07$ & 0.14 & $4 \pm 0.04$ & 0.08 & $5.7 \pm 0.05$ & 0.10 \\
\hline $1^{\circ}$ instar & $6 \pm 0.06$ & 0.12 & $3 \pm 0.03$ & 0.06 & $3.4 \pm 0.03$ & 0.06 \\
\hline $2^{\underline{o}}$ instar & $5 \pm 0.05$ & 0.10 & $2 \pm 0.02$ & 0.04 & $3.1 \pm 0.03$ & 0.06 \\
\hline $3^{0}$ instar & $4 \pm 0.04$ & 0.08 & $2 \pm 0.02$ & 0.04 & $3.0 \pm 0.03$ & 0.06 \\
\hline $4^{\circ}$ instar & $8 \pm 0.08$ & 0.16 & $2 \pm 0.02$ & 0.04 & $3.9 \pm 0.04$ & 0.08 \\
\hline $5^{\circ}$ instar & $16 \pm 0.15$ & 0.30 & $5 \pm 0.05$ & 0.10 & $8.8 \pm 0.08$ & 0.16 \\
\hline Pupa & $20 \pm 0.42$ & 0.84 & $8 \pm 0.17$ & 0.34 & $12.6 \pm 0.26$ & 0.52 \\
\hline Adult & $27 \pm 0.75$ & 1.50 & $5 \pm 0.14$ & 0.28 & $11.4 \pm 0.32$ & 0.64 \\
\hline
\end{tabular}

$\mathrm{Ma}=$ Maximum; $\mathrm{Mi}=$ Minimum; $\mathrm{Av}=$ Average; $\mathrm{R}=$ Range $($ days $)$.

Table 3 - Biological parameters (mean \pm standard error of mean) of Utetheisa ornatrix (Lepidoptera: Arctiidae) after feeding on Crotalaria juncea (Fabaceae) plants in the laboratory

\begin{tabular}{|c|c|c|c|c|}
\hline Parameters & Du (days) & $\mathrm{R}$ & & \\
\hline \multirow{2}{*}{ First eggs to adult deaths } & $51.9 \pm 1.44$ & 2.88 & & \\
\hline & $\mathrm{Qu}$ & $\mathrm{Av}$ & $\mathrm{R}$ & $\mathrm{Nf}$ \\
\hline Lifetime fecundity & 172 to 763 & $459.3 \pm 12.76$ & 25.52 & 14 \\
\hline Oviposition & 3 to 17 & $10.3 \pm 0.29$ & 0.58 & 14 \\
\hline
\end{tabular}

$\mathrm{Du}=$ Duration; $\mathrm{Qu}=\mathrm{Quantity} ; \mathrm{Av}=$ Average; $\mathrm{Nf}=$ Number of females; $\mathrm{R}=$ Range (days/number).

First instar of $U$. ornatrix caterpillars were $2 \mathrm{~mm}$ long; head with shiny black color and width greater than the body. Thorax and abdomen with yellow light color, with black spots, of which leave long bristles. Bristles of the back of caterpillar with black color and the sides, white. The prothorax has a large black spot. The color of thoracic legs was similar to the head and the abdomen, similar to the body. The caterpillars are brown with light patches on the segments.

The head of the second instar of $U$. ornatrix caterpillars is black and the body brown with light spots. Dorsal spots and two laterals per segment resembled the clearings lines 
that accompanied the body. These segments had other white spots. Bristles arranged as in the first instar. Thoracic legs with dark color and the abdominal, with the same of body.

The head of the third and fourth instars of $U$. ornatrix caterpillars is yellow, with dark spots. Body with opaque black color and thorax and the last abdominal segments with lighter shade and yellowish white patches. Black bristles and longs of the back, with the thoracic segments and the last abdominal segments the distal portion with white color.

Maximum length of the $U$. ornatrix caterpillars in the fifth instar, $3 \mathrm{~cm}$. Head with yellowish brown color and two dark spots near to the suture and in the region of the eyes. The size of these spots was variable and few caterpillars showed no staining. Bristles sparse in these spots. Body with black color and blotches that were united with those of segments resembling yellow lines along the entire the body length. These lines were in the dorsal region (one line) and lateral (two lines), with small yellow spots and white between them.

Fifth instar of $U$. ornatrix caterpillars were black tubers with black bristles on the back of the caterpillar and white on the sides. Black bristles and long in the thoracic region to the last abdominal segments with white color in the distal portion. Caterpillars with light color in the belly. Thoracic legs with shiny black color and the abdominal with color similar to the body (Figures 1A and 1B).

The length of the $U$. ornatrix pupae was from 1.2 to $1.5 \mathrm{~mm}$ with smooth texture and dark brown color. Thorax, abdomen, and wings with yellow spots. Dark respiratory stigmata on the yellow spots. Few small thorns and scattered by the segments. Eight thorns with a curved edge in the back of the abdomen (Figure 1C).

The width of $U$. ornatrix adults was $4 \mathrm{~mm}$. Head with white color and black spots. Type antennae: filiform; ocelli behind the antennae and white labial palps with black extremity. Thorax with white color with black spots and white abdomen. Forewings triangular type, with the upper face of pinkish and front edge with a narrow band red, interrupted of space to space by a gray stain with a black spot. A series of three black spots in the center of this board, toward the center of the wing, and a red stripe on the lateral edge limited in both sides by a gray stain with a series of black spots. This board had white fringe. Females with wings darker than the male and live red with black spots on the underside of the wings and that corresponded, before, those ashes of the upper face. Hind wings wide and rounded with the upper face with white color stained of black and red spots on the front edge. Adults with white fringe on the edges, except in the anterior and inferior, who had the same color of the anterior. Belly adult body white, with black spots scattered around the thorax and forming two lateral series on the abdomen (Figures 1D, 1E, and 1F).

Unlike most moths, U. ornatrix was, generally, diurnal. This pest damaged mainly the seeds of $C$. juncea, but fed also on the leaves of this plant. The females laid eggs on both sides of the leaves and in the concave portion of $C$. juncea pods. Eggs were grouped, side by side. The caterpillars feed on egg chorion after hatching and, posteriorly, started to feed on leaves. Caterpillars penetrated into the pods by a circular hole and devoured the seeds, leaving only droppings and other debris. Caterpillars abandoned this location by the same entrance hole after consuming the seeds. In the laboratory, caterpillars pupated at the top of the PVC cages and in the branches of the plants where they fed. The caterpillar spun a cocoon with silken threads, within which immobilized it to pass the pre-pupa and pupa. In the field, traces similar of exuvia to the laboratory were found, but no pupae were found, possibly due to the type of sampling used.

The abundance of $C$. externa was higher in the vegetative stage than of flowering and pods stages and of $U$. ornatrix in the flowering stage of $C$. juncea. The vegetative stage of C. juncea had a similar abundance of these species. On the other hand, the abundance of $U$. ornatrix was greater than the abundance of $C$. externa in the stages of flowering and pods of this culture (Table 4).

\section{DISCUSSION}

The development of $U$. ornatrix with leaves of $C$. juncea was similar to an artificial 

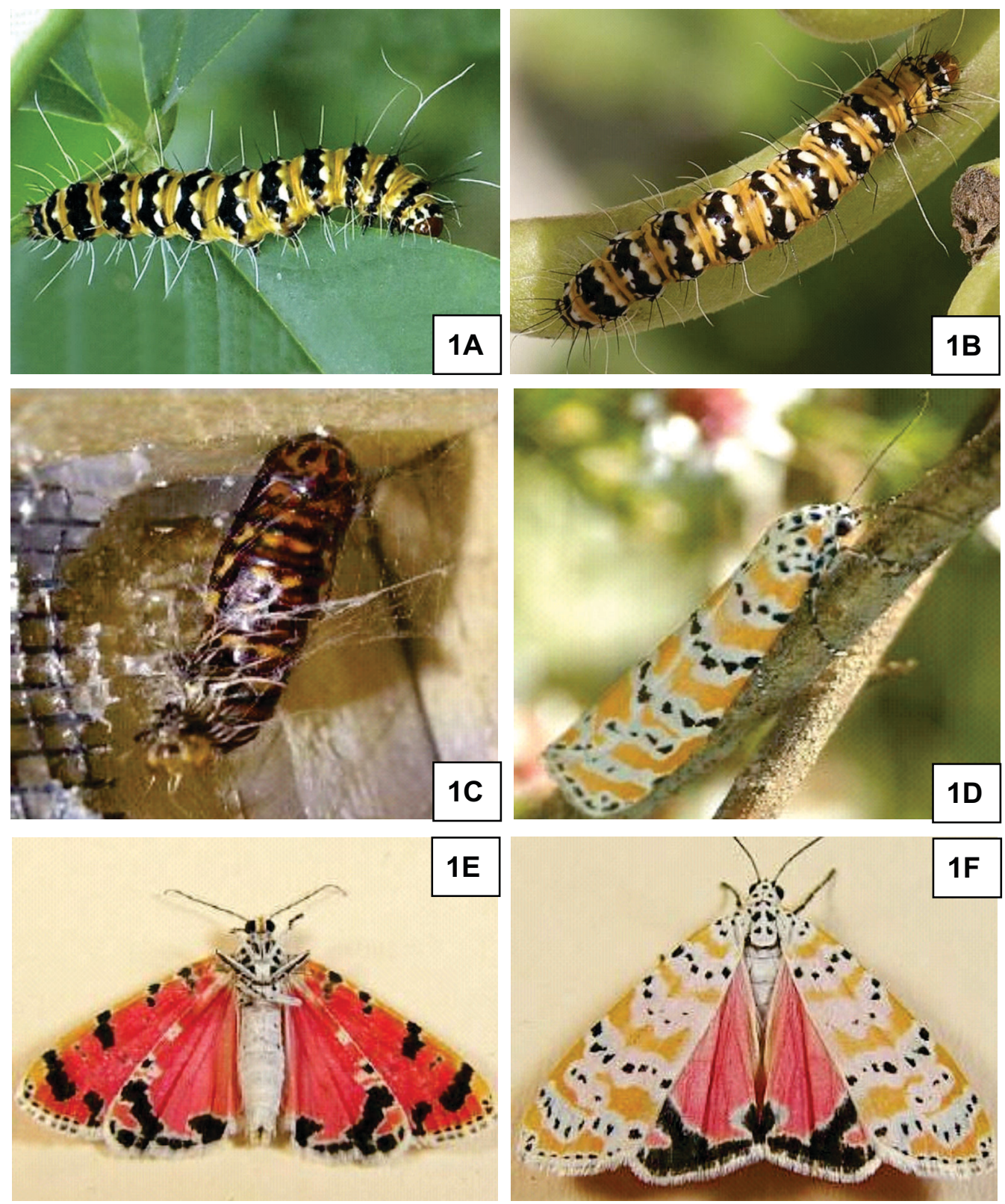

Figures 1 - Caterpillars (A and B); cocoon (C), and adults (D, E, and F) of Utetheisa ornatrix (Lepidoptera: Arctiidae).

Table 4 - Total of individuals (mean \pm standard error of mean) of Chrysoperla externa (Neuroptera: Chrysopidae) and Utetheisa ornatrix (Lepidoptera: Arctiidae) collected from plants of Crotalaria juncea (Fabaceae) in Sete Lagoas, Minas Gerais State, Brazil

\begin{tabular}{|l|c|c|r|c|}
\hline \multicolumn{1}{|c|}{ Stage $^{1 / /}$} & Chrysoperla externa & $\mathrm{R}$ & Utetheisa ornatrix & $\mathrm{R}$ \\
\hline Vegetative & $7.28 \pm 0.94 \mathrm{aA}$ & 1.88 & $8.52 \pm 0.58 \mathrm{bA}$ & 1.16 \\
\hline Flowers & $4.06 \pm 0.52 \mathrm{bB}$ & 1.04 & $12.66 \pm 1.20 \mathrm{aA}$ & 1.40 \\
\hline Pods & $0.88 \pm 0.11 \mathrm{cB}$ & 0.22 & $8.34 \pm 0.54 \mathrm{bA}$ & 1.08 \\
\hline VC $(\%)$ & & \multicolumn{2}{|c|}{34.67} & \\
\hline
\end{tabular}

${ }^{1 /}$ Averages followed by the same small letter per column, or capital letter per line, do not differ by Tukey's test $(P<0.05)$. VC $=$ Variation Coefficient. $\mathrm{R}=$ Range (number). 
diet, showing no effect of the food offered to the caterpillars in the number of instars of this insect (Signoretti et al., 2008). Some caterpillars of $U$. ornatrix had six instars, which suggest the effect of sex (male and female) in the number of them: caterpillars of Thyrinteina arnobia Stoll, 1782 (Lepidoptera: Geometridae) have five and six instars that originated males and females of this species, respectively, with leaves of Eucalyptus urophyla (Myrtaceae) (Oliveira et al., 2005). An artificial diet rich in beans and brewer's yeast was adequate for $U$. ornatrix, because the crops of $C$. juncea are only deployed during part of the year, enabling the delivery of plant material to the caterpillars (Wander et al., 2007; Martins et al., 2009). The rearing of $U$. ornatrix with an artificial diet could enable the development of biological studies and of control methods with the parasitoid Cotesia sp. (Hymenoptera: Braconidae), often found parasitizing their caterpillars (Signoretti et al., 2008). Caterpillars of $U$. ornatrix require plants of Crotalaria spp. as food, due to the presence of chemical compounds, such as hydroxydanaidal, the precursor of their sex pheromone (Campo et al., 2007). Their females select males, who hijacked much of the alkaloid, which are larger and probably with a greater quantity of sperm to fertilize their eggs (Conner et al., 1990).

The longest duration of the egg and pupal stages of $U$. ornatrix with the plants of $C$. juncea than with an artificial diet (4.5 and 10.3 days, respectively), suggests that a food rich in beans and brewer's yeast is suitable for the maintenance of this insect (Signoretti et al., 2008). On the other hand, the duration of the larval stage of $U$. ornatrix was lower with plants of $C$. juncea than with an artificial diet (26.5 days). A nutritious artificial food reduces the larval period of this insect, when their caterpillars can be attacked by natural enemies (Signoretti et al., 2008). The duration of the larval stage of $U$. ornatix, of 25.92 and 21.05 days after feeding on leaves or seeds of Crotalaria pallida Aiton (Fabaceae), respectively, suggests that this defoliator prefers the seeds of this plant, with a higher content of PAs (Ferro et al., 2006). Younger adults of $U$. ornatrix with a diet rich in alkaloids laid eggs earlier, and had a shorter duration from the larval to adult stage in the laboratory, suggesting a loss of resistance and susceptibility to natural enemies (Campo et al., 2005; Partridge et al., 2005).

The higher viability of the egg stage of $U$. ornatrix with the plants of $C$. juncea than with a diet rich in beans and brewer's yeast (84.2\%) suggests the need of gradual adaptation to artificial food in future generations (Signoretti et al., 2008). The lower survival of $U$. ornatrix caterpillars in the laboratory after predation on leaves than on the green seeds of C. pallida suggests the expenditure of energy to pierce the pods and reach the seeds. However, this can be offset because the caterpillars are better protected inside the pods against natural enemies. This was shown with a pupal survival of $89.3 \%$ and $70 \%$ with leaves or seeds of C. pallida, respectively (Ferro et al., 2006).

The number of eggs per female of $U$. ornatrix with the plants of $C$. juncea was greater than this defoliator with an artificial diet (239.5 eggs) (Signoretti et al., 2008), leaves (244.4 eggs), or seeds (297.75 eggs) of C. pallida (Ferro et al., 2006) or leaves of Crotalaria incana (Fabaceae) (Cogni et al., 2010), indicating that native hosts are better for this Lepidoptera than those introduced. The number of eggs per eggs masses of $U$. ornatrix (20 eggs) may have been an adaptation against predation by larvae of Chrysopidae, because eggs masses with three or fewer eggs were more predated. Eggs masses with four or more eggs of $U$. ornatrix were on average three eggs inspected by the larvae of Chrysopidae, but were not preyed, which may be due to the presence of alkaloids on them (Eisner et al., 2000).

The characteristics and habits of the caterpillars of $U$. ornatrix, including in the pods of $C$. juncea were similar to this insect that laid their eggs on the leaves and their caterpillars feeding on seeds in the green pods of C. pallida (Ferro et al., 2006). Adults from the caterpillars that fed on the green seeds were preyed less frequently by the spider Nephila clavipes, 1767 (Araneae: Nephilidae), when fed on the leaves of C. pallida (Ferro et al., 2006). Eggs of this insect have been rejected by Coccinellidae beetles (Dussourd et al., 1988), larvae of Ceraeochrysa cubana, 1861 (Neuroptera: Chrysopidae) (Eisner et al., 2000) and the ant Leptothorax longispinosus, 1863 
(Hymenoptera: Formicidae) (Hare \& Eisner, 1993). Coleomegilla maculata De Geer, 1775 and Cycloneda sanguinea, 1763 (Coleoptera: Coccinellidae), Diabrotica speciosa, 1824 and Cerotoma arcuatus , 1791 (Coleoptera: Chrysomelidae) and the unidentified larvae of Coccinellidae (Tavares et al., 2011b), also soil organisms have been observed in the cultures of C. juncea in Sete Lagoas, Minas Gerais State, Brazil (Tavares et al., 2011c), showing the importance of this culture as a refuge for harmful-insects and natural enemies. The green seeds of $C$. pallida have five times more PAs than their leaves, which were sequestered by the caterpillars and transferred to the adults of $U$. ornatrix; this may protect this insect, but this chemical defense did not prevent the fact that they were preyed by ants Ectatomma quadridens, 1793, Camponotus crassus, 1862 (Ferro et al., 2006) and Camponotus blandus, 1858 (Hymenoptera: Formicidae) (Guimarães Junior et al., 2006). Caterpillars of $U$. ornatrix, in the field do not come immediately in the pods of Crotalaria spp. after hatching, remaining in the early stages near the apex of the leaves, but the second or third, their caterpillars penetrate the pods (Ferro et al., 2006).

The greater abundance of $U$. ornatrix than of $C$. externa in the flowering and pods stages of $C$. juncea suggests that this predator avoids crops of this Fabaceae after the issuance of flowers. The content of total alkaloids in the plants of Adenanthera intermedia Merr and Crotalaria spectabilis Roth (Fabaceae), Senecio jacobaea L. (Asteraceae), Senecio longilobus Benth., Senecio riddellii Torr. \& A. Gray and Senecio spartioides Torr. \& A. Gray (Asteraceae) was maximum at the beginning of flowering or sprouting after cutting, thereby suggesting a greater possibility of the incorporation of these compounds by caterpillars of $U$. ornatrix in this period (Johnson et al., 1985). The abundance of adult and immature of $U$. ornatrix damaging leaves, flowers, and seeds of Crotalaria breviflora (Fabaceae) and C. spectabilis was higher in May of 2008 in Alagoas State, Brazil (Dias et al., 2009). Caterpillars of $U$. ornatrix migrated from the host plant for pupating in shelters in the bark of trees in the vicinity of the culture (Dias et al., 2009). Furthermore, they may move to other plants species in search of food after the defoliated plants of Crotalaria spp., preferentially when the activity of predatory ants is low, for example, at sunrise (Ferro et al., 2006).

Some biological and ecological characteristics of $C$. externa and $U$. ornatrix on the organic crop of $C$. juncea were studied. The abundance of adults and larvae of $C$. externa was lower in the flowering and pods stages of C. juncea, respectively, when the postures of $U$. ornatrix are present. During these stages, $C$. externa may be reared with alternative hosts, and when the crops of $C$. juncea are scarce, an artificial diet should be used for rearing this defoliator in the laboratory for biological research and the development of biological control tactics.

\section{ACKNOWLEDGEMENTS}

The authors thank Dr. José Carlos Cruz (EMBRAPA Maize and Sorghum, Brazil) for the cultivation of Crotalaria juncea organic, Dr. Antônio Marcos Coelho (EMBRAPA Maize and Sorghum, Brasil) for the availability of soil analysis, and Dr. J.P. Michaud (Kansas State University, USA) for help in the discussion of this paper. The authors also thank Mike Cruz for providing the figure 1A; Karen Finch, figure 1B; Machele White, figure 1C; Giff Beaton, figure $1 \mathrm{D}$, and Bob Patterson, figures $1 \mathrm{E}$ and $1 \mathrm{~F}$. The financial support from "Conselho Nacional de Desenvolvimento Científico e Tecnológico (CNPq)", "Coordenação de Aperfeiçoamento de Pessoal de Nivel Superior (CAPES)", and "Fundação de Amparo a Pesquisa do Estado de Minas Gerais (FAPEMIG)" is gratefully acknowledged. The authors would also like to thank WResource for English corrections and editing this manuscript.

\section{LITERATURE CITED}

ÁBRAHÁM, L.; MARKÓ, V.; VAS, J. Investigations on a Neuropteroid community by using different methods. Acta Phytopathol. Entomol. Hung., v. 38, n. 1-2, p. 199-207, 2003.

CALONEGO, J. C.; ROSOLEM, C. A. Soybean root growth and yield in rotation with cover crops under chiseling and no-till. Europ. J. Agron., v.33, n. 3, p. $242-249,2010$. 
CAMPO, M. L.; SMEDLEY, S. R.; EISNER, T. Reproductive benefits derived from defensive plant alkaloid possession in an arctiid moth (Utetheisa ornatrix). Proc. Natl. Acad. Sci. USA, v. 102, n. 38, p. 13508-13512, 2005.

CAMPO, M. L.; POSSNER, S. T.; EISNER, T. Corematal function in Utetheisa ornatrix (Lepidoptera: Arctiidae) Hydroxydanaidal is devoid of intrinsic defensive potency. Chemoecology, v. 17, n. 1, p. 19-22, 2007.

COGNI, R. Resistance to plant invasion? A native specialist herbivore shows preference for and higher fitness on an introduced host. Biotropica, v. 42, n. 2, p. 188-193, 2010

COGNI, R.; FUTUYMA, D. J. Local adaptation in a plant herbivore interaction depends on the spatial scale. Biol. J.

Linn. Soc., v. 97, n. 1, p. 494-502, 2009.

CONNER, W. E. et al. Courtship pheromone production and body size as correlates of larval diet in males of the arctiid moth, Utetheisa ornatrix. J. Chem. Ecol., v. 16, n. 2, p. 543-552, 1990.

DIAS, N. S. et al. Occurrence of Utetheisa ornatrix (L., 1758) (Lepidoptera: Arctiidae) attacking Crotalaria spp. (Fabaceae) in Alagoas State, Brazil. R. Caatinga, v. 22, n. 1, p. 1-2, 2009.

DINIZ, J. A. F. et al. The three phases of the ensemble forecasting of niche models: geographic range and shifts in climatically suitable areas of Utetheisa ornatrix (Lepidoptera, Arctiidae). R. Bras. Entomol., v. 54, n. 3, p. 339-349, 2010.

DUSSOURD, D. E. et al. Biparental defensive endowment of eggs with acquired plant alkaloid in the moth Utetheisa ornatrix. Proc. Natl. Acad. Sci. USA, v. 85, n. 16, p. $5992-5996,1988$

EISNER, T. et al. Chemical defense against predation in an insect egg. Proc. Natl. Acad. Sci. USA, v. 97, n. 4, p. $1634-1639,2000$

FERRO, V. G.; GUIMARÃES, P. R.; TRIGO, J. R. Why do larvae of Utetheisa ornatrix penetrate and feed in pods of Crotalaria species? Larval performance vs. chemical and physical constraints. Entomol. Exper. Appl., v. 121, n. 1, p. 23-29, 2006.

GUIMARÃES JUNIOR, P. R. et al. Extrafloral nectaries as a deterrent mechanism against seed predators in the chemically protected weed Crotalaria pallida (Leguminosae). Austral Ecol., v. 31, n. 1, p. 776-782, 2006.

HARE, J. F.; EISNER, T. Pyrrolizidine alkaloid deters ant predators of Utetheisa ornatrix eggs: effects of alkaloid concentration, oxidation state, and prior exposure of ants to alkaloid-laden prey. Oecologia, v. 96, n. 1, p. 9-18, 1993.

HARTMANN, T. et al. Acquired and partially de novo synthesized pyrrolizidine alkaloids in two polyphagous arctiids and the alkaloid profiles of their larval food-plants J. Chem. Ecol., v. 30, n. 2, p. 229-254, 2004
HOOKS, C. R. R. et al. Using marigold (Tagetes spp.) as a cover crop to protect crops from plant-parasitic nematodes. Appl. Soil. Ecol., v. 46, n. 3, p. 307-320, 2010.

J, X. H. et al. Variability for the presence of pyrrolizidine alkaloids in Crotolaria juncea L. Pharmazie, v. 60, n. 8, p. 620-622, 2005.

JOHNSON, A. E.; MOLYNEUX, R. J.; MERRILL, G. B. Chemistry of toxic range plants. Variation in pyrrolizidine alkaloid content of Senecio, Amsinckia, and Crotalaria species. J. Agric. Food Chem., v. 33, n. 1, p. 50-55, 1985.

MARTINS, M. D. et al. Crop type influences soil aggregation and organic matter under no-tillage. Soil Till. Res., v. 104, n. 1, p. $22-29,2009$

MESCHEDE, D. K.; FERREIRA, A. B.; RIBEIRO, C. C. Evaluation of weed suppression using different crop covers under Brazilian cerrado soil conditions. Planta Daninha, v. 25, n. 3 , p. $465-471,2007$.

MIYAZAWA, K. et al. Intercropping green manure cropseffects on rooting patterns. Plant Soil, v. 331, n. 1-2, p. 231-239, 2010.

MONQUERO, P. A. et al. Effect of green fertilizers on the suppression of different species of weeds. Planta Daninha, v. 27 , n. 1, p. $85-95,2009$.

MORRIS, J. B.; KAYS, S. E. Total dietary fiber variability in a cross section of Crotalaria juncea genetic resources.

Crop Sci., v. 45, n. 1, p. 1826-1829, 2005

ODHIAMBO, J. J. O. Potential use of green manure legume cover crops in smallholder maize production systems in Limpopo province, South Africa. Afr. J. Agr. Res., v. 6, n. 1, p. 107-112, 2011.

OLIVEIRA, H. N. et al. Rearing of Thyrinteina arnobia (Lepidoptera: Geometridae) on guava and Eucalyptus in laboratory. Braz. Arch. Biol. Technol., v. 48, n. 5, p. 801-806, 2005.

PARTRIDGE, L.; GEMS, D.; WITHERS, D. J. Sex and Death: What Is the Connection? Cell, v. 120, n. 1, p. 461472, 2005.

QUEIROZ, R. L. et al. Weed suppression and organic green corn production in no tillage system. Planta Daninha, v. 28, n. 2, p. 263-270, 2010.

RUSSEL, D. F. MSTAT-C Statistical Package Program ver. 2.1. East Lansing, Michigan State University, 1989.

SIGNORETTI, A. G. C. et al. Biology and thermal requirements of Utetheisa ornatrix (L.) (Lepidoptera: Arctiidae) reared on artificial diet. Braz. Arch. Biol. Technol., v. 51, n. 4, p. 647-653, 2008. 
TAVARES, W. S. et al. Prey consumption and development of Chrysoperla externa (Neuroptera: Chrysopidae) on Spodoptera frugiperda (Lepidoptera: Noctuidae) eggs and larvae and Anagasta kuehniella (Lepidoptera: Pyralidae) eggs. Maydica, v. 56, n. 3, p. 283-289, 2011a.

TAVARES, W. S. et al. Harmful Chrysomelidae and beneficial Coccinellidae on organically grown Crotalaria juncea (L.) (Fabaceae). Trends Entomol., v. 7, n. 1, p. 37-44, 2011 b.
TAVARES, W. S. et al. Soil organisms associated to the weed suppressant Crotalaria juncea (Fabaceae) and its importance as a refuge for natural enemies. Planta Daninha, v. 29, n. 3, p. $473-479,2011 \mathrm{c}$

WANDER, A. E. et al. Economic viability of small scale organic production of rice, common bean and maize in Goiás state, Brazil. J. Agric. Rural Develop. Trop., v. 108, n. 1, p. $51-58,2007$ 